\title{
Linfoma Ósseo
}

\section{Bone Lymphoma}

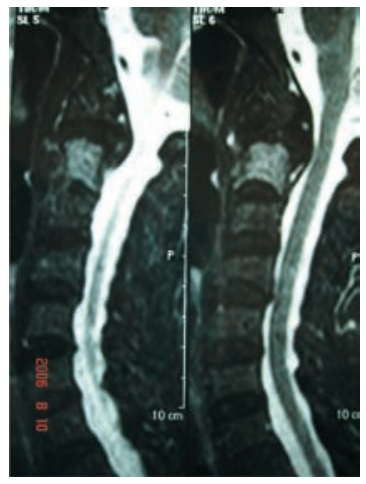

Figura 1 - RNM em T2, sagital: lesão hiperintensa em corpo de C2.

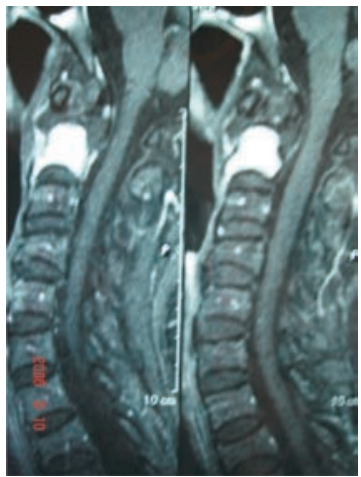

Figura 2 - RNM em T1, sagital, com contraste e supressão de gordura: lesão com captação de contraste em C2.

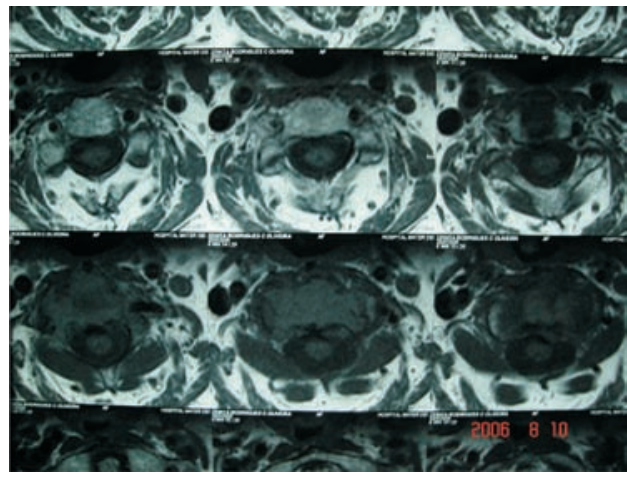

Figura 3 - RNM em T1, horizontal: lesão hipo-intensa, com destruição óssea de C2, com invasão de partes moles.

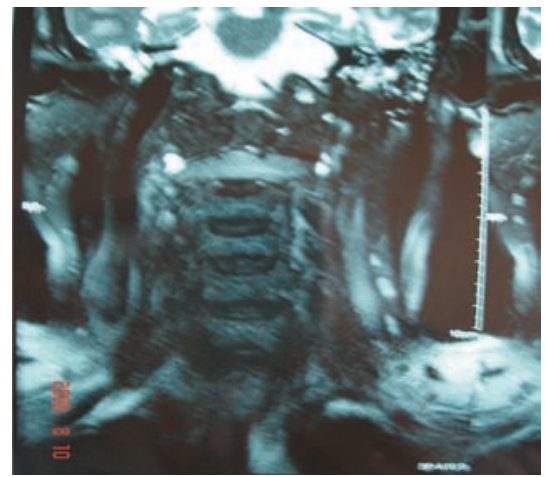

Figura 4 - RNM em T2, coronal: lesão hiperintensa em C2 que poupa o odontóide (paciente com os odontoideum).

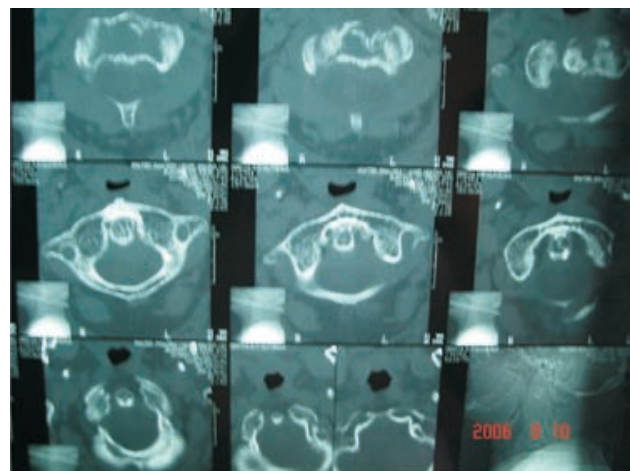

Figura 5 - TC com janela óssea, horizontal: destruição óssea de $C 2$, sem lesão do odontóide, e sem formação de pannus ou subluxação de C1-C2.

Paciente ZRCO, 72 anos, feminina, há 3 meses iniciou cervicalgia e limitação importante da flexão, extensão e rotação bilateral da coluna cervical, além de artrite em tornozelo esquerdo. A TC de coluna cervical mostrou alterações em $\mathrm{Cl}$ e C2 sugestivas de pannus reumatóide, o que motivou o encaminhamento para a reumatologia. Apresentava VHS, PCR, FR e anti-CCP negativos. Com os novos exames de imagem afastou-se a hipótese de pannus e levantou-se a de neoplasia. A biópsia com imunoistoquímica revelou lesão linfoproliferativa do tipo linfoma não-Hodgkin de pequenas células-B, com extensa diferenciação plasmocitária.

Caso encaminhado pelas residentes Lílian S. Santos, Janaina G. Netto e Fernanda F. Silva; Claudia L. S. Neiva, médica assistente; Eduardo Jose do Rosario e Souza, coordenador da Residência em Reumatologia; Paulo M. Pádua, chefe do Serviço de Reumatologia da Santa Casa de Belo Horizonte (MG). Lílian Santuza Santos. Rua Tenente Garro, 137/1001 CEP 30240-360, Belo Horizonte, MG, e-mail: lilian.santuza@terra.com.br 